\title{
LOGISTICS OF CONTROLLING IMPLEMENTATION IN CONDITIONS OF MANUFACTURING ENTERPRISE
}

\author{
Annamária Behúnová \\ Technical University of Košice, Institute of Earth Resources, Letná 9, Košice, Slovak Republic, EU, \\ annamaria.behunova@tuke.sk \\ Lucia Knapčíková \\ Technical University of Košice, Department of Industrial Engineering and Informatics, Bayerova 1, Prešov, \\ Slovak Republic, EU, lucia.knapcikova@ @uke.sk (corresponding author) \\ Marcel Behún \\ Technical University of Košice, Institute of Earth Resources, Letná 9, Košice, Slovak Republic, EU, \\ marcel.behun@tuke.sk
}

Keywords: production costs, controlling, logistics implementation

Abstract: Market saturation creates a competitive environment among manufacturers, causing constant competition for customers. The offer affects the consumer by many factors, but we consider the selling price of the product to be the main influence factor. In order to achieve a competitive price of the product, it is necessary to know not only the market but mainly the production costs of the company. Since production costs form the largest part of the sales price of the product, it is important for the manufacturing company to monitor and regularly adjust these costs so that the price of the product is competitive in the domestic or foreign market. As the cost of production, which in this particular undertaking is based on internal analysis and accounting documents, accounts for the largest part of the sales price of the product, it is important that the manufacturing company monitors and regularly adjusts it so that the product price is competitive on the domestic or foreign market. The aim of the presented research was to analyse the internal financial statements of a particular manufacturing company, to point out the critical values of production costs and to find a suitable solution for their subsequent optimization. In order to achieve the tactical, short-term goals of the company on the domestic and mainly foreign market, it is necessary to regularly control the costs of the company using a suitably chosen implementation management logistics, which is currently a progressive tool of business development.

\section{Introduction}

The term controlling originated in the late 19th century in America as a system of rules in economic theory and practice. It originally referred to a specific type of planning and control in the area of accounting and finance. Over time, it has developed into other business functions. Later he penetrated Europe. In the 1960s, the first knowledge of controlling appeared in Germany, where it quickly spread, especially in large companies, and later became interested in medium and small businesses. The beginning of controlling in Slovakia arose after the revolution the 1989 [1]. Controlling represents an important role in the company management system, it influences the understanding of controlling role in management. The main role of managers in a company is to prepare an appropriate decision-making environment and to provide detailed and timely information [1]. Controlling creates a tool to help businesses maintain and achieve a predetermined goal [2]. In other words, to achieve the planned objectives by ensuring and using organizational resources. It monitors the difference between real power and standard power, i.e. deviation. It investigates why a deviation occurs between them and helps to propose and take corrective actions. The aim of controlling is to plan and facilitate business coordination [3]. By introducing of controlling, the company wants to achieve performance standards, compare real performance with these standards and, if necessary, take corrective measures. Performance standards are most often expressed in monetary terms, such as profit, loss, revenue, expense or other terms (units produced, number of defective products, quality level or customer service) [4]. At present, controlling is considered a subsystem of the management system, which is applied in large and small enterprises, institutions and banks, while not looking at the ownership, organizational and legal form. Controlling serves as a management tool and is firstclass support for managers [1]. In theory and practice, it was formed into three basic concepts [5]:

- Accounting concept - help controlling fulfilment of goals and tasks through the specificity of orientation on information obtained from accounting. The obtained information comes from the accounting information system, represented mainly by financial and internal accounting. The main task of the concept is to focus accounting as a future-oriented managerial tool, with futureoriented calculation systems as a prerequisite.

- The concept focused on information - helps controlling the provision of the required information base of the company and expresses the 
information goal. The concept is again based on accounting as the main source of management information, where the obtained information serves as information systems for management and economic consulting. Controlling acts as a support for business management with information. The information obtained is adjusted and coordinated for use in business management.

- The concept focused on the management system is the most comprehensive and eliminates the disproportionately narrowed space of controlling in the management of accounting, or management information system. Controlling is considered as a subsystem of the company radiation system. The role of the concept is to limit controlling in relation to the management system.

Controlling is introduced in the company for various reasons and different time aspects. In terms of the time, we divide Strategic controlling (long-term) and Operative controlling (short-term). Short-term operative controlling is then divided into Internal controlling, Financial controlling and Investment controlling. Strategic and operational controlling are interlinked functional areas that complement each other [4].

\subsection{Cost controlling}

The scope of corporate controlling provides several possibilities for controlling division. The basic and most important aspects of the division are: functional area (research, development, supply, production, sales), area of activity (complex, production-financial, financial), time horizon (strategic, operational) and control content (costs, performance, investments, marketing, personnel, environmental protection) [6].

The main factor of cost controlling in a company are costs. Costs are an important criterion for the company, which is necessary for assessing the effectiveness of the company and as a decision-making tool. Costs are incurred in each business unit, process, activity, employee, etc. [7]. It consists of a systemic approach to cost management in an enterprise, which observes costs incurred at specific business centres, with different business functions, observes costs through accounting and integrated systems. It analyses, plans and manages costs in the company, controls their incidence and influence on the economic result, economic efficiency of the company. It observes the basic strategic objective of the company, namely the development of the company through the maximum economy, which consists of cost-effective and efficient cost management and achieving economic efficiency in the form of profit [7].

Cost controlling is a system that deals with observation and evaluation of company costs, finding deficiencies in costing, costing, cost analysis and evaluation (Figure 1). It provides cost reduction and seeks viable cost savings options at all business levels and processes. Cost controlling is a necessary component in management accounting because it deals with cost accounting, calculations, budgeting, and tax accounting. The outputs of cost controlling are reflected in the financial management of the company, where the cost controlling occurs at the operational and tactical level of management, the results of which are applied in parts of the strategic controlling of the company [8].

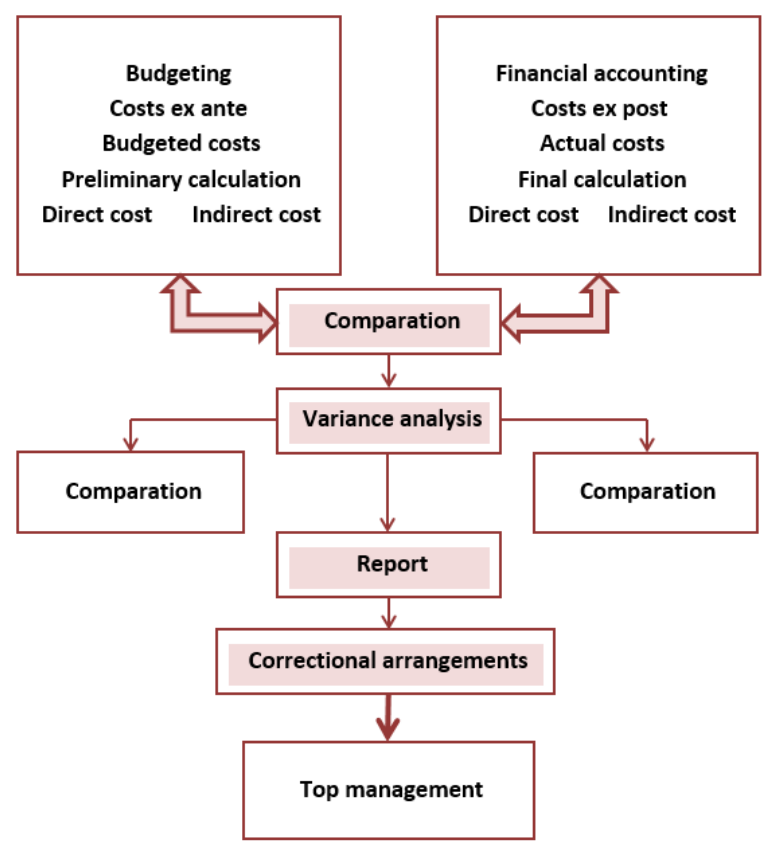

Figure 1 Ecological deficit / reserve, [2]

\subsection{Internal cost controlling}

Cost controlling belongs to in-plant controlling, whose main task is to inform the company about costs incurred in each area of business activity and help to make a profit. The secondary tasks are to improve planning, cost decision-making and capacity utilization of the enterprise, to continually innovate the company's calculation and cost system [7]. As a system, cost controlling helps the company to apply modern cost planning methods, organize costs and time to individual processes within the company, create a cost tracking overview, identify hidden cost savings points and address the company's financial situation [8]. Cost controlling is a practical tool that manages the business economy through a detailed system. The system consists of a detailed structured margin, which is a special part of economic management. It results from accounting data based on cost calculations. It optimizes from an enterprise-wide perspective and in terms of products, segments, and places of responsibility. It helps to solve the financial situation of the company and discovers hidden places to save the company costs. It is thus a means 
of off-accounting processing of accounting data established for tactical economic decisions [8].

The calculation system consists of individual types of calculations and suitably selected calculation methods (Table 1). The purpose of the calculation is to identify and determine the costs that have been and will be consumed for a certain amount of performance in a given period. Types of calculations are divided in terms of time, method of compilation, cost structure, and utilization of production capacity [9]. Calculation methods are methods that observe and determine the actual cost of performance. For methods, it is necessary to know the subject of the calculation, the method of recalculating the cost of the costing object, the method of recalculating the cost per unit of costing and the cost structure [9].

Table 1 Calculation system [10]

\begin{tabular}{|c|c|}
\hline Types of calculations & Calculation methods \\
\hline \multirow{2}{*}{$\begin{array}{l}\text { 1. In terms of time: } \\
\text { - provisional } \\
\text { - resulting }\end{array}$} & 1. Division calculation \\
\hline & 2. Calculation in associated production \\
\hline \multirow{2}{*}{$\begin{array}{l}\text { 2. In terms of compilation: } \\
\text { - total cost calculation } \\
\text { - calculation of variable costs }\end{array}$} & 3. Surcharge calculation \\
\hline & $\begin{array}{l}\text { 4. Activity based costingactivity based } \\
\text { costing - ABC }\end{array}$ \\
\hline \multirow{2}{*}{$\begin{array}{c}\text { 3. In terms of cost structure: } \\
\text { - continuous } \\
\text { - gradual }\end{array}$} & 5. Phase and step calculation \\
\hline & 6. Custom calculation \\
\hline \multirow{2}{*}{$\begin{array}{l}\text { 4. In terms of production capacity utilization: } \\
\qquad \begin{array}{r}\text { - static } \\
\text { - dynamic }\end{array}\end{array}$} & 7. Differential calculation \\
\hline & $\begin{array}{l}\text { 8. Simple / tiered calculation of incomplete } \\
\text { costs }\end{array}$ \\
\hline
\end{tabular}

\section{Methodology}

Through the values of production cost items, it is possible to evaluate the total production cost of the enterprise. By our research, the internal accounting documents of the joint stock enterprise with its registered office in the Slovak Republic were analysed. This enterprise operates in the field of industrial production specifically the production of gate systems. By comparing these values, it was possible to define the order of the items and thus determine which item generates the highest costs for the company. The average cost of production is shown in the following tables (Table 2, Table 3, Table 4),

where:

ODC - other direct costs, MAT - material,

PO - production overhead,SO - supply overhead,

AO - assembly overhead.

An analysis of the cost items of the year 2016 revealed that the sum of average costs is $9075.26 €$. The largest item (according to Table 2) is the sum of the average costs of consumed material, which represents $71.93 \%$ of the total cost of $6527.95 €$.

Table 2 Calculation of production costs (2016) [authors own processing]

\begin{tabular}{|c|c|c|c|c|c|c|c|}
\hline \multicolumn{7}{|c|}{ Production costs items } \\
\hline Product types: & $\begin{array}{c}\text { Average } \\
\text { ODC }\end{array}$ & $\begin{array}{c}\text { Average } \\
\text { MAT }\end{array}$ & $\begin{array}{c}\text { Average } \\
\text { wage }\end{array}$ & $\begin{array}{c}\text { Average } \\
\text { PO }\end{array}$ & $\begin{array}{c}\text { Average } \\
\text { SO }\end{array}$ & $\begin{array}{c}\text { Average } \\
\text { mounting }\end{array}$ & $\begin{array}{c}\text { Average } \\
\text { AO }\end{array}$ \\
\hline A & 34,42 & 831,67 & 32,16 & 106,36 & 82,80 & 19,67 & 77,93 \\
\hline B & 0,00 & 2421,23 & 33,34 & 149,75 & 241,36 & 22,81 & 91,23 \\
\hline C & 9,24 & 595,38 & 70,24 & 216,49 & 59,54 & 25,50 & 101,98 \\
\hline D & 0,00 & 299,06 & 30,80 & 101,64 & 29,91 & 4,12 & 16,48 \\
\hline E & 107,30 & 2380,61 & 89,32 & 294,76 & 238,06 & 52,02 & 208,08 \\
\hline $\begin{array}{c}\text { Sum of } \\
\text { average costs: }\end{array}$ & $\mathbf{1 5 0 , 9 6}$ & $\mathbf{6 5 2 7 , 9 5}$ & $\mathbf{2 5 5 , 8 6}$ & $\mathbf{8 6 9 , 0 0}$ & $\mathbf{6 5 1 , 6 7}$ & $\mathbf{1 2 4 , 1 2}$ & $\mathbf{4 9 5 , 7 0}$ \\
\hline
\end{tabular}

An analysis of the cost items of the year 2017 found that the sum of the average cost was $6365.76 €$. The largest item (according to Table 3 ) is the sum of the average cost of consumed material, which makes up $75.55 \%$ of the total cost of $4809.36 €$. 
LOGISTICS OF CONTROLLING IMPLEMENTATION IN CONDITIONS OF MANUFACTURING ENTERPRISE Annamária Behúnová; Lucia Knapčíková; Marcel Behún

Table 3 Calculation of production costs (2017) [authors own processing]

\begin{tabular}{|c|c|c|c|c|c|c|c|}
\hline \multicolumn{8}{|c|}{ Production costs items } \\
\hline Product types: & $\begin{array}{l}\text { Average } \\
\text { ODC }\end{array}$ & $\begin{array}{l}\text { Average } \\
\text { MAT }\end{array}$ & $\begin{array}{l}\text { Average } \\
\text { wage }\end{array}$ & $\begin{array}{c}\text { Average } \\
\text { PO }\end{array}$ & $\begin{array}{l}\text { Average } \\
\text { SO }\end{array}$ & $\begin{array}{l}\text { Average } \\
\text { mounting }\end{array}$ & $\begin{array}{c}\text { Average } \\
\text { AO }\end{array}$ \\
\hline $\mathbf{A}$ & 75,52 & 708,98 & 28,62 & 94,39 & 70,46 & 18,43 & 73,71 \\
\hline B & 0,00 & 1951,05 & 22,01 & 74,13 & 194,48 & 14,35 & 57,41 \\
\hline $\mathbf{C}$ & 0,00 & 282,19 & 55,08 & 181,77 & 28,22 & 15,45 & 61,80 \\
\hline D & 0,00 & 167,64 & 31,94 & 105,41 & 16,76 & 3,43 & 13,73 \\
\hline $\mathbf{E}$ & 0,00 & 1699,50 & 0,00 & 0,00 & 169,95 & 29,87 & 119,48 \\
\hline $\begin{array}{l}\text { Sum of average } \\
\text { costs: }\end{array}$ & 75,52 & 4809,36 & 137,65 & 455,70 & 479,87 & 81,53 & 326,13 \\
\hline
\end{tabular}

An analysis of the cost items of the year 2018 found that the sum of the average cost is $8856.34 €$. The largest item (according to Table 4) is the sum of the average cost of consumed material, which makes $82.71 \%$ of the total cost of $6961.47 €$.

Table 4 Calculation of production costs (2018) [authors own processing]

\begin{tabular}{|c|c|c|c|c|c|c|c|}
\hline \multicolumn{8}{|c|}{ Production costs items } \\
\hline Product types: & $\begin{array}{l}\text { Average } \\
\text { ODC }\end{array}$ & $\begin{array}{l}\text { Average } \\
\text { MAT }\end{array}$ & $\begin{array}{l}\text { Average } \\
\text { wage }\end{array}$ & $\begin{array}{c}\text { Average } \\
\text { PO }\end{array}$ & $\begin{array}{c}\text { Average } \\
\text { SO }\end{array}$ & $\begin{array}{l}\text { Average } \\
\text { mounting }\end{array}$ & $\begin{array}{c}\text { Average } \\
\text { AO }\end{array}$ \\
\hline $\mathbf{A}$ & 25,67 & 828,32 & 31,59 & 104,44 & 82,50 & 23,90 & 95,58 \\
\hline B & 0,00 & 1330,30 & 25,46 & 83,61 & 130,13 & 12,76 & 51,04 \\
\hline $\mathbf{C}$ & 0,00 & 353,58 & 51,89 & 171,25 & 35,38 & 10,63 & 41,20 \\
\hline D & 0,00 & 230,37 & 34,52 & 113,90 & 23,54 & 16,23 & 64,90 \\
\hline $\mathbf{E}$ & 0,00 & 4218,90 & 4,68 & 15,43 & 421,89 & 44,55 & 178,20 \\
\hline $\begin{array}{c}\text { Sum of } \\
\text { average costs: }\end{array}$ & 25,67 & 6961,47 & 148,14 & 488,63 & 693,44 & 108,07 & 430,92 \\
\hline
\end{tabular}

An analysis of the cost items of the production costs of the observed years (2016, 2017 and 2018) revealed that for enterprise the average cost of consumed material causes the highest cost of production for each year. Average material costs comprise the largest part of the company's production costs and consist of $71.93 \%$ in $2016,75.55 \%$ in 2017 and $82.71 \%$ in 2018 .
Based on a comparison of the analysed values (Figure 2 ), it was found that the average material costs increase each year as a percentage. The percentage increase in material costs is almost $11 \%$ over the three years of the observed period (the difference between 2018 and 2016, $82.71 \%-71.92 \%=10.78 \%)$.

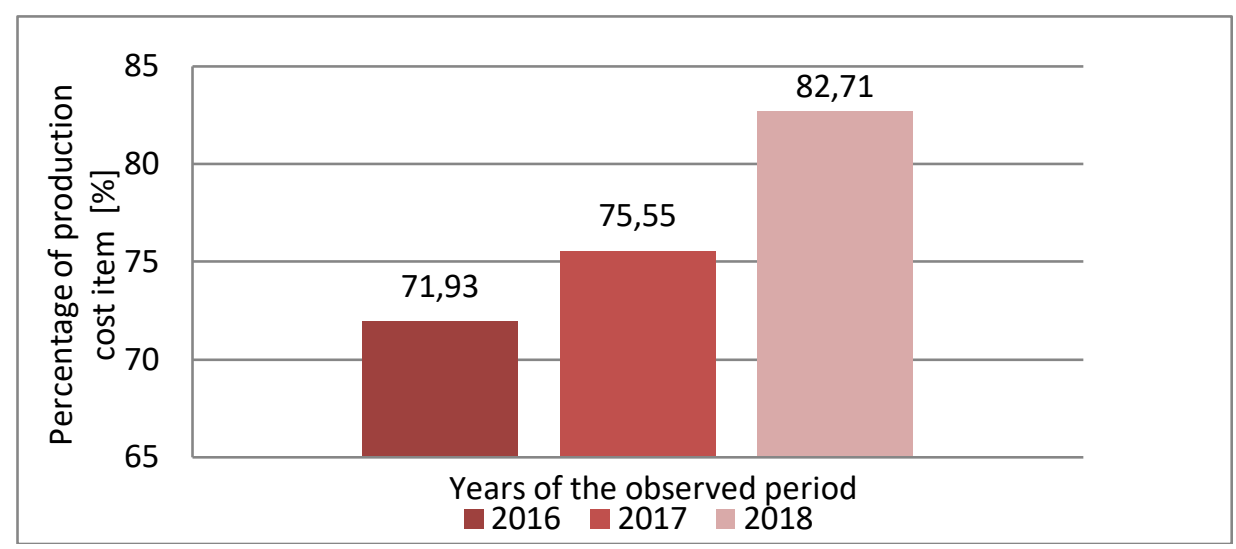

Figure 2 Comparison of the analysed values [authors own processing] 


\section{Results}

Implementation of controlling in the enterprise is a very important and necessary step for the company to meet the predetermined goal of exporting products to neighbouring countries such as Austria, France, Germany, Switzerland, and possibly Norway and Finland [11]. The introduction of controlling will be used mainly for controlling production costs in order to reduce their value and optimize the material economy. The cost of consumed production material represents the largest part of the cost, proportionally containing up to $70-80 \%$ of the total cost of production. In order to reduce these costs, it is necessary to know the entire material flow, from material design, manufacturer and supplier selection, through purchasing, material storage, processing and treatment to the final product and the management and recycling of material waste. Cost reduction is an important factor for the company in 2019, as it plans to increase production in 2020 and start exporting its products abroad. Therefore, it is necessary to adopt a predictive approach to the implementation of controlling, which is mandatory for workers and management. Based on the complicated algorithm of controlling into the company management system, it is necessary to divide the implementation into these four essential stages, based on the preparation, design, introduction, and realization.

\subsection{The first stage - preparations of controlling}

Preparing the introduction of controlling is a fundamental and essential stage for the company, whose main task is to attract and convince the management of company for the need to use controlling. It is important to obtain management approval to start implementation. Management consists of prudent advisors and senior management who are accustomed to certain standards and any change in their subconscious raise's uncertainty. Given the new goal of the company, it is necessary to create and implement a new management concept with a focus on the foreign market. The foreign market has its standards and qualities, so it is necessary to know the market requirements perfectly $[11,12]$. Competitive position on the foreign market can be achieved only by quality work, goodwill, and satisfied customers.

The role of controlling is to meet the set goal therefore, it is necessary to define and precisely set the objective of controlling implementation in the company. The main goal in this particular company is to achieve a reduction in the manufacturing costs of the company, which was revealed by a financial analysis of internal costs. Specifically, these are the average costs of consumed materials for the period 2016 - 2018, which are part of the calculation of production costs. Production costs need to be cut short, ideally year 2019/2020.

The next step of the first stage is to train each employee on the introduction and use of controlling, to familiarize them with the controlling objective and next year's 2020 plan. To give employees a detailed idea of creating lower sub-tiers of corporate division management and incorporate them into the organizational structure of each management level.

Trained employees need to create a continuing education program, through which employees will acquire sufficient knowledge and knowledge of the use of controlling. Sufficient education will only be achieved through active participation in training sessions that will be held for individual corporate levels of management, from managers, economic departments, through managers of gateway operations to the actual production operations.

The preparation stage is an analytical-diagnostic stage that analyses the current state of the achieved results in the company and points out the need for the implementation of controlling, the current shortcomings for achieving the target and the need to reduce production costs. By analysing the current state of the division managers obtain an overview of the economic state of the division, which can be used to determine in detail the ways and methods of reducing production costs and thus eliminate unwanted problems that affect the achievement of the division's products export to the foreign market.

\subsection{Second stage - projecting of controlling}

The second stage of design is needed to define in detail the options for remedying the current situation and creates the procedures needed to reduce business costs. Controlling is necessary to monitor the analysed high average cost of consumed material. Define each area using consumed material. The cost of consumed material is influenced by several factors. It is necessary to focus on every step that deals with the material. To find out the correctness of the material utilization design in the technological process, to verify the methods of material purchase and supplier's choice, to analyse the methods of material processing and methods of material waste management. By defining corrective actions, a controlling plan will be created to help reduce production costs. It shall determine the remedial action of each process of handling purchased, transforming and marketing material [12]. It is necessary to reach new suppliers of materials and get a new quotation for the purchase of new material, check the technical designs and production processes of manufactured products in order to simplify their production and handling of materials, pay attention to the inconvenience of production and supervise ways of using.

After the processing and application of remedial measures, it is important to continually re-evaluate the results obtained, i.e. knowledge of material handling, and consequently to derive further sub-measures that guide the achievement of the objective.

This is followed by the design and projecting of the system of business and strategic planning. Changes are made in the organizational structure of the company, the choice of appropriate management style is required. It is important to take into account the initiative, suggestions, and decisions of senior executives. In an enterprise, it is 
necessary to change the authoritative style of management to collective and thus prove to all employees that the set goal can only be proved by collective work. Evaluate the collective work by rebuilding the motivational system of additional employee evaluation, change the corporate culture.

The last step of the second stage is to change the control-planning system of the company and make the implementation of an information system conditional on the interconnection of all divisions in the company. Using the information system, the company will have an overview of all divisions at the same time and will be able to create a material flow between divisions, thereby optimizing the material inventory and directing material logistics. For the company is a suitable SAP information system, which includes, among other modules, a controlling module.

\subsection{The third stage - the introduction of controlling}

The penultimate stage consists of the introduction of controlling into the company, where the selected controlling team is already implementing practical controlling applications based on the selected concept. The chosen concept consists of optimization methods to reduce costs and material consumption. Controlling team is professionally educated and has practical experience in using controlling. The team is also complemented by external workers who are also part of the other divisions of the company and provide the team with a summary of enterprise.

Before starting the implementation, it is necessary to identify the main controller who supervises and is responsible for the overall course and changes caused by the implementation and function of controlling as well as for the functioning of the complete system. After fulfilling these steps, the decision to start work on corporate controlling is accepted. Acceptance is subject to the overall size of the enterprise.

\subsection{The fourth stage - the realization of controlling}

The realization stage is the last stage of the implementation of the controlling system of the company, in which the actual processes of reducing the production costs focused on consumed material through of controlling are already carried out. New methods of material utilization and processing are used, so a new material management system is applied in the company. Changes in the economy are due to the change in material suppliers, the processing of waste and scrap material, which reduces the analysed average cost of consumed material. By reducing the cost of consumed material, the total production costs of the company are also reduced in proportion.
For the long-term functioning of the controlling system in the company, it is necessary to constantly repeat the evaluation of the effectiveness of controlling methods in order to maintain competitiveness in the domestic and foreign markets in the long term $[13,14]$. For the progressive operation of the company with regard to building a continuously increasing competitiveness, it is necessary to implement controlling throughout the company.

After achieving the set objectives, it is necessary to evaluate the effectiveness of the whole implementation and to compare the assumptions received with the achieved results, or to deduce future changes in controlling.

The last step of the last phase of implementation is the systematic completion of the overall project, where the implementation team compares the achieved result with the required initial target of the company [15]. It is necessary to evaluate the achieved results, production quality, meeting deadlines and the overall success of the implementation team. The overall success of controlling implementation in the company can only be assessed and determined to be correct several years after its introduction. At the end of this phase, future business prospects need to be determined at this stage.

\section{Conclusions}

The production costs of the company, the largest part of the total internal costs. Therefore, in order to achieve business goals and maintain market competitiveness, production costs need to be constantly monitored and reduced. The main objective of this work was to investigate the internal costs of the enterprise. By examining the financial statements of previous years 2016 - 2018, we created wellarranged tables of internal costs, which show the average cost of each item of the calculation formula for each type of products sold and the sum of the average cost of each item of the calculation formula for the whole year for all types of products simultaneously. Subsequently, for a more detailed analysis, we chose only those items of the calculation formula that constitute the production costs of the corporate division. By analysing the items of production cost, we have made a comparison of items that pointed to the item with the highest value of average production costs for each one observed year. The highest cost of production for each observation year for the enterprise is caused by the item of the average cost of consumed material, which represents $71.93-82.71 \%$ of the total cost of production. By comparing the average cost of consumed material, we found out that the cost of the material increases annually as a percentage. The cost of consumed material has increased by up to $11 \%$ over the observation period, so costs need to be constantly monitored and reduced. For this reason, we have identified opportunities for the company to reduce costs and recommend the implementation of controlling described in four stages of implementation. 


\section{References}

[1] CHODASOVÁ, Z.: Podnikový controlling - nástroj manažmentu, Bratislava, STATIS, 2012. (Original in Slovak)

[2] BEHÚN, M., BEHÚNOVÁ, A., KNAPČÍKOVÁ, L.: Controlling podniku, Košice, Technická univerzita v Košiciach, 2017. (Original in Slovak)

[3] MESÁROŠ, F., MESÁROŠ, P., SELÍN, J.: Controlling nákladov na stavebné procesy, Košice, Výskumný ústav stavebnej informatiky, 2013. (Original in Slovak)

[4] ESCHENBACH, R. et al.: Controlling, Praha, ASPI Publishing, 2000. (Original in Czech)

[5] REICHMANN, T.: Controlling Concepts of Management Control, Controllership and Rations, USA, Springer, 1997.

[6] MANN, R.: Controlling - Metóda prosperujícího podnikání, Praha, Profit, a.s., 1992. (Original in Czech)

[7] FOLTÍNOVÁ, A., KALAFUTOVÁ, L'.: Vnútropodnikový controlling, Bratislava, ELITA, 1998. (Original in Slovak)

[8] FOLTÍNOVÁ, A. et al:: Nákladový controlling, Bratislava, Iura Edition, 2011. (Original in Slovak)

[9] FREIBERG, F.: Finančný controlling. Koncepcia finančnej stability firmy, Bratislava, ELITA, 1996. (Original in Slovak)

[10] KUPKOVIČ, M.: Náklady podniku. Komplexný pohl'ad na náklady, Bratislava, Sprint, 1999. (Original in Slovak)

[11] OLÁH, J., SADAF, R., MÁTÉ, D., POPP, J.: The influence of the management success factors of logistics service providers on firms' competitiveness, Polish Journal of Management Studies, Vol. 17, No. 1, pp. 175-193, 2018.

doi:10.17512/pjms.2018.17.1.15

[12] HRUŠECKÁ, D., PIVNIČKA, M., BORGES LOPES, R.: Logistics management as a system constraint, Polish Journal of Management Studies, Vol. 15, No. 1, pp. 76-87, 2017. doi:10.17512/pjms.2017.15.1.08

[13] DOBROVIČ, J., URBAŃSKI, M., GALLO, P., BENKOVÁ, E., ČABINOVÁ, V.: Balanced scorecard concept as a tool of strategic management and its usage in the construction industry, Polish Journal of Management Studies, Vol. 18, No. 2, pp. 59-72, 2018. doi:10.17512/pjms.2018.18.2.05

[14] STRAKA, M., ROSOVÁ, A.,LENORT, R., BESTA, P., ŠADEROVÁ, J.: Principles of computer simulation design for the needs of improvement of the raw materials combined transport system, Acta Montanistica Slovaca, Vol. 23, No. 2, pp.163-174, 2018.

[15] MATVEEVA I., KHOMENKO E.: Formation of support for small enterprises in the process of business incubation with the application of logistic chains, Acta Logistica, Vol. 5, No. 1, pp.15-18, 2019, doi:10.22306/al.v5i1.85

\section{Review process}

Single-blind peer review process. 